\title{
ZARZĄDZANIE NIERUCHOMOŚCIAMI MIESZKANIOWYMI W PERSPEKTYWIE OCZEKIWAŃ POTENCJALNYCH NABYWCóW
}

\author{
Martyna Musiał \\ Politechnika Częstochowska \\ Wydział Zarządzania
}

\begin{abstract}
Streszczenie: Celem opracowania jest ukazanie, ocena i analiza oczekiwań nabywców nieruchomości mieszkaniowych. W części empirycznej artykułu przedstawiono charakterystykę nieruchomości mieszkaniowych oraz specyfikę zarządzania lokalami mieszkaniowymi. W części badawczej wykorzystano kwestionariusz ankietowy, natomiast metodą badawczą było badanie sondażowe. Badanie przeprowadzono wśród mieszkańców Częstochowy. Wyniki ankiety odnoszą się do preferencji zakupowych nabywców nieruchomości mieszkaniowych na terenie miasta. Pozyskane w tym badaniu informacje $\mathrm{z}$ jednej strony nakreślają obraz potrzeb klientów, a z drugiej mogą być sugestią dla podmiotów tworzących podaż na rynku nieruchomości.
\end{abstract}

Słowa kluczowe: mieszkanie, rynek nieruchomości, nieruchomość mieszkaniowa, zarządzanie nieruchomością mieszkaniową

DOI:10.17512/znpcz.2018.1.05

\section{Wprowadzenie}

Nieruchomości coraz częściej stają się przedmiotem zainteresowania rzeszy ludzi. Dzieje się tak, gdyż życie bez nieruchomości nie byłoby możliwe. Do niedawna zaspakajały one głównie potrzebę ,dachu nad głową”. W miarę upływu lat zakres funkcji nieruchomości został poszerzony. Zaczęto postrzegać je między innymi jako inwestycje, powiększenie czy też zabezpieczenie kapitału własnego (Sitek 2010, s. 10).

W zakresie tematyki nieruchomości bardzo ważnym zagadnieniem okazuje się zarządzanie nieruchomościami. Niegdyś zarządzanie nieruchomościami było oparte na działaniach zapewniających właściwą gospodarkę finansowo-ekonomiczną, bezpieczeństwo użytkowania nieruchomości, odpowiednią gospodarkę energetyczną, utrzymanie nieruchomości $\mathrm{w}$ odpowiednim stanie technicznym oraz inwestowanie w nieruchomość. Obecnie w ustawodawstwie nie występuje definicja zarządzania nieruchomościami. Ostateczna treść terminu oraz zakres czynności, którymi jest objęta nieruchomość, wynika z umowy zawartej pomiędzy zarządcą a właścicielem, wspólnotą mieszkaniową lub inną jednostką (Ustawa z dnia 21 sierpnia 1997 r. ..., art. 185). 


\section{Istota nieruchomości mieszkaniowych}

Rynek nieruchomości mieszkaniowych definiowany jest jako miejsce spotkań popytu mieszkaniowego z podażą mieszkań. Na podstawie tej relacji następuje zawarcie transakcji rynkowej (Laszek 2006, s. 155). W związku z tym głównym celem na rynku nieruchomości mieszkaniowych jest relacja przyszłego użytkownika z nieruchomością (Lemańska-Majdzik, Tomski 2014, s. 6).

Rynek nieruchomości mieszkaniowych to rynek o lokalnym charakterze. Specyficzne cechy owego rynku warunkują postępowanie zakupowe potencjalnych nabywców działających na nim. Zatem determinanty, jak i motywy procesu decyzyjnego mają istotę indywidualną (Gorzeń-Mitka, Grabiec 2015, s. 298). Wybór nieruchomości mieszkaniowych jest zatem całkowicie własny oraz modyfikowalny - możliwość zmiany lokalu mieszkalnego (Lis 2008, s. 17).

Poruszając tematykę nieruchomości mieszkaniowych, należy wyjaśnić definicję lokalu mieszkalnego. Mieszkaniem jest lokal powstały za pośrednictwem przebudowy lub budowy, a tym samym staje się miejscem wykorzystywanym na potrzeby mieszkalne (Bryx 2006, s. 74). Nieruchomościami mieszkaniowymi nie są lokale o zbiorowym zamieszkaniu, takie jak: domy opieki, domy studenckie, internaty, hotele pracownicze (Baranowski 2008, s. 167).

Lokal mieszkalny, w porównaniu z resztą budynków, powinien podołać odgórnie narzuconym wymogom. Jednym $z$ podstawowych kryteriów jest właśnie zapewnienie całodobowego pobytu lokatora bez narażenia jego zdrowia bądź życia. $\mathrm{W}$ związku z tym użytkownik mieszkania do godnej egzystencji potrzebuje pomieszczeń o odpowiednim rozmiarze oraz podstawowego wyposażenia. Dzięki tym aspektom każdy lokal mieszkalny jest swego rodzaju indywidualnością umożliwiającą samodzielne prowadzenie gospodarstwa domowego (Bończak-Kucharczyk 2014, s. 36).

W myśl ustawy o własności lokali za samodzielny lokal mieszkalny możemy uznać „,wydzieloną trwałymi ścianami w obrębie budynku izbę lub zespół izb przeznaczonych na stały pobyt ludzi, które wraz z pomieszczeniami pomocniczymi służą zaspokajaniu ich potrzeb mieszkaniowych" (Ustawa z dnia 14 czerwca 1994 r. ..., art. 2). Zapis ustawy uwzględnia istnienie dodatkowych pomieszczeń przynależnych do lokalu, takich jak: garaż, strych, komórka, piwnica. Warto nadmienić, że pomieszczenia tego typu nie muszą być połączone z budynkiem, ważne, aby zostały usytuowane na tym samym gruncie. Terminologia lokalu mieszkalnego została poszerzona w ustawie o najmie lokali mieszkalnych, która dodatkowo zawiera informacje o możliwości wynajęcia powierzchni mieszkaniowej (Ustawa z dnia 2 lipca 1994 r. ..., art. 57). Przedmiotem transakcji o tym charakterze może być lokal bądź dom. Powierzchnia ta zostaje wykorzystana $\mathrm{w}$ celach mieszkaniowych lub jako miejsce prowadzenia własnej działalności z zakresu sztuki oraz kultury (Bończak-Kucharczyk 2014, s. 7).

Lokal mieszkalny powinien spełnić narzucone odgórnie normy techniczne. Standardy stworzone przez Ministra Infrastruktury dotyczą szczególnie mieszkań na terenie budynków wielorodzinnych. Zgodnie z powyższymi ustaleniami mieszkanie poza powierzchnią mieszkaniową musi zawierać pomieszczenia takie jak: 
łazienka, kuchnia bądź wnęka kuchenna, miejsce składowania w postaci piwnicy czy też komórki oraz korytarz zwany powierzchnią komunikacji wewnętrznej (Rozporządzenie Ministra Infrastruktury z dnia 12 kwietnia 2002 r. ..., art. 9-12).

\section{Specyfika zarządzania nieruchomościami mieszkaniowymi}

Zarządzaniem nieruchomościami mieszkalnymi zajmuje się zarządca nieruchomości. Podmiot ten dba o utrzymanie, jak i podwyższenie wartości danej nieruchomości. Zabieg taki ma na celu długotrwałe użytkowanie nieruchomości przez ogół konsumentów z sektora publicznego, jak i prywatnego. Jednak zarządca nieruchomości przede wszystkim dba o interesy swego klienta, a więc właściciela danej nieruchomości, umożliwiając mu zdobycie maksymalnych zysków ze sprzedaży bądź najmu nieruchomości (Sobczak 2010, s. 16).

Pomimo nieistniejącego już art. 185 ust. 1 pkt 5 u.g.n. (ustawa o gospodarce nieruchomościami) nadal należy uważać, iż utrzymanie nieruchomości w odpowiednim stanie jest jedną z najistotniejszych wytycznych zarządcy nieruchomości. W celu utrzymania lub powiększenia wartości nieruchomości należy przeprowadzić konserwacje, remonty, właściwą eksploatację nieruchomości oraz zapewnić jej mieszkańcom bezpieczeństwo i porządek. W związku z tym zarządca nieruchomości powinien dokonać oceny istniejącego stanu rzeczy oraz opracować plan konserwacji, szczególnie uwzględniając wielkość środków niezbędnych do ich wykonania (Nowak, Skotarczak 2013, s. 209).

Kolejnym etapem zarządzania nieruchomością mieszkaniową jest kontrola stanu nieruchomości. Działanie to obejmuje sprawdzenie zgodności przeznaczenia i spełnienia wymogów ochrony środowiska oraz utrzymania obiektu w należytym stanie estetycznym i technicznym (Bończak-Kucharczyk 2014, s. 312-315).

Obowiązki zarządcy nieruchomości to również zapewnienie lub inspirowanie właścicieli nieruchomości do utrzymania odpowiedniej gospodarki finansowo-ekonomicznej oraz gospodarki energetycznej (Nalepka 2006, s. 9). Mówiąc o aspektach finansowo-ekonomicznych, należy dopilnować, aby właściciel nieruchomości łożył odpowiednie środki na jej utrzymanie (Gawron 2010, s. 10). Do dalszych zadań należy zapewnienie odpowiedniej gospodarki energetycznej. To działania oparte na: podłączeniu nieruchomości do sieci (elektrycznej, cieplnej, gazowej), wyposażeniu lokalu mieszkalnego w urządzenia (grzejniki, piece, urządzenia pomiarowe), zawarciu odpowiedniej umowy z dostawcami usług energetyczno-gazowych, opłaceniu należności dostawcom, przeprowadzaniu konserwacji urządzeń i dokonywaniu potrzebnych ulepszeń w postaci instalacji urządzeń czy docieplanie ścian (Bończak-Kucharczyk 2014, s. 312-315).

Ostatnim elementem zarządzania nieruchomością mieszkaniową jest inwestowanie w nieruchomość. Inwestowanie w nieruchomość to obowiązek właściciela, a nie zarządcy nieruchomości. Jednakże w myśl z nieprawomocnego już art. 185 ust. 1 pkt 6 u.g.n. działanie takie może stanowić obowiązek zarządcy nieruchomości, wynika to z zawartej umowy. W związku z tym inwestowanie w nieruchomość obejmuje dokonywanie ulepszeń służących poprawie walorów funkcjonalnych i użytkowych nieruchomości. Ponadto w tym zakresie dokonuje się poprawy mają- 
cej na celu uzyskanie dodatkowych przychodów z nieruchomości - przebudowa lub rozbudowa obiektu budowlanego.

Omawiając specyfikę zarządzania nieruchomościami mieszkaniowymi, warto nadmienić, iż obowiązki, jakimi będzie trudnił się zarządca nieruchomości, zależą od woli obu stron. Właściciel, jak i zarządca powinni jednak dołożyć wszelkich starań, by oczekiwania potencjalnych nabywców lokalu mieszkalnego zostały zaspokojone (Najbar, Uhruska 2006, s. 149-150).

\section{Analiza uzyskanych wyników badań}

Grupę badawczą stanowiło 100 mieszkańców miasta Częstochowy. Dobór wielkości próby uzasadniony jest stale malejącą liczbą mieszkańców miasta. Wybór 100 ankietowanych okazał się jednak wystarczający do ukazania wiedzy o zróżnicowaniu oczekiwań potencjalnych nabywców nieruchomości mieszkaniowych.

Badanie zostało przeprowadzone od października do grudnia 2017 roku. Wśród ankietowanych przeważali mężczyźni, których było 61 . W grupie badanych zdecydowanie przeważały osoby między 21 . a 30 . rokiem życia - stanowiły one $53 \%$ ogółu ankietowanych. Respondenci w wieku 31-40 lat stanowili 31\% badanych, natomiast ludzie w grupie wiekowej 18-20 lat oraz 41-50 lat stanowili po 7\% respondentów. Warto nadmienić, że w ankiecie nie wzięli udziału mieszkańcy powyżej 60. roku życia.

Wśród osób badanych dominowało wykształcenie wyższe - 57\% ankietowanych. Na drugim miejscu znaleźli się mieszkańcy o wykształceniu średnim, których było $29 \%$. Natomiast na samym końcu, z wynikiem 2\%, znaleźli się respondenci o wykształceniu gimnazjalnym. W badaniu nie wzięły udziału osoby o wykształceniu podstawowym.

Z uzyskanych danych wynika, że 32\% respondentów posiada dwuosobowe gospodarstwo domowe. Kolejne $25 \%$ osób badanych twierdzi, że ich gospodarstwo zamieszkują 3 osoby. Natomiast 17\% osób ankietowanych przyznaje, że w obrębie ich gospodarstwa domowego przebywają 4 osoby. Wśród 18\% respondentów znajdują się osoby mające 5 lub więcej osób w gospodarstwie domowym. Natomiast jedynie 8 respondentów mieszka samotnie.

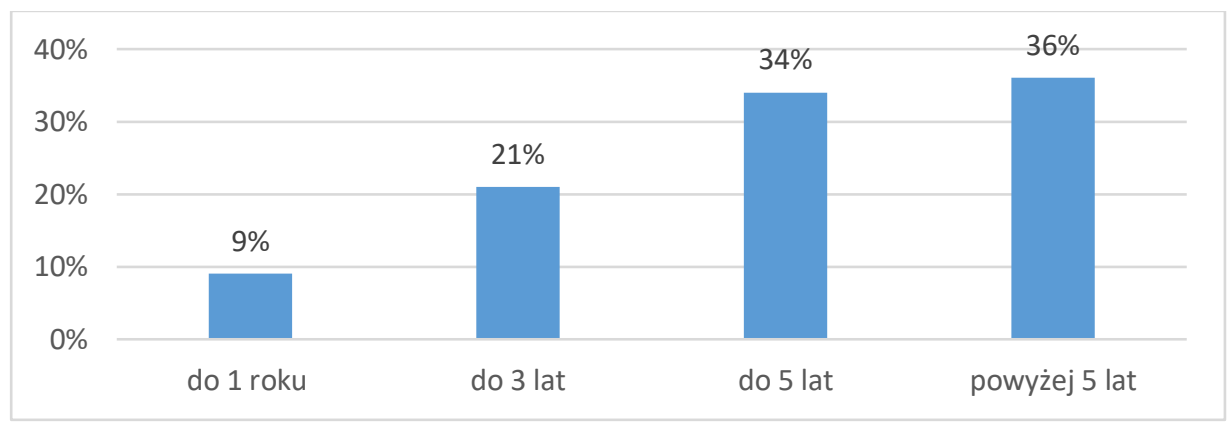

Rysunek 1. Orientacyjny czas planowanego zakupu mieszkania

Źródło: Opracowanie własne na podstawie badań ankietowych 
Większość ankietowanych (91\%) w najbliższym czasie nie planuje zakupu mieszkania w Częstochowie. Pogłębiając jednak to pytanie, dostrzec można, że ponad połowa respondentów $(70 \%)$ respondentów zamierza dokonać zakupu mieszkania w czasie 5 lub powyżej 5 lat. Natomiast $21 \%$ badanych uważa, że mieszkanie nabędzie w przeciągu 3 najbliższych lat. Niestety tylko 9\% spośród respondentów pragnie nabyć mieszkanie w przeciągu 1 roku (Rysunek 1).

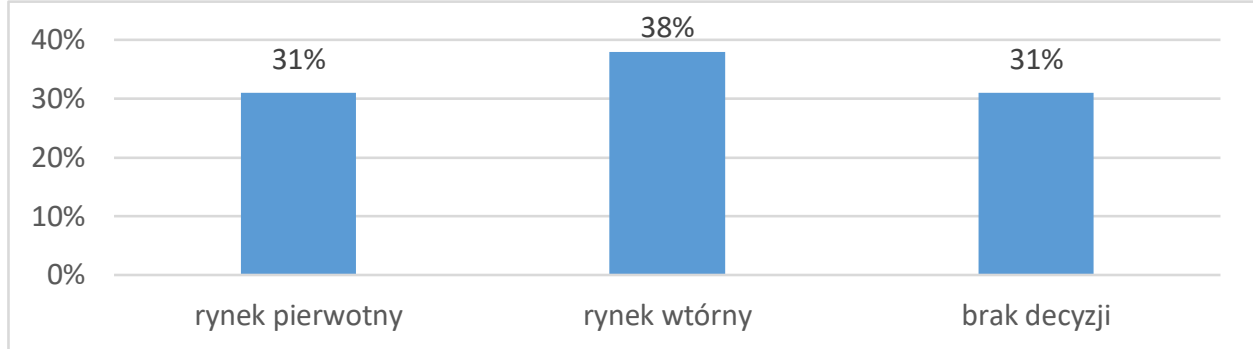

\section{Rysunek 2. Preferowany rynek nieruchomości mieszkaniowych}

Źródło: Opracowanie własne na podstawie badań ankietowych

$\mathrm{Z}$ zebranych danych wynika, że $31 \%$ osób zainteresowanych zakupem mieszkania nie podjęło jeszcze ostatecznej decyzji co do tego, czy będzie to pierwotny, czy też wtórny rynek nieruchomości. Wśród pozostałych ankietowanych $38 \%$ pytanych osób oznajmiło, że planuje nabyć nieruchomość mieszkaniową z rynku wtórnego, zaś 31\% zdecyduje się na zakup mieszkania z rynku pierwotnego (Rysunek 2).

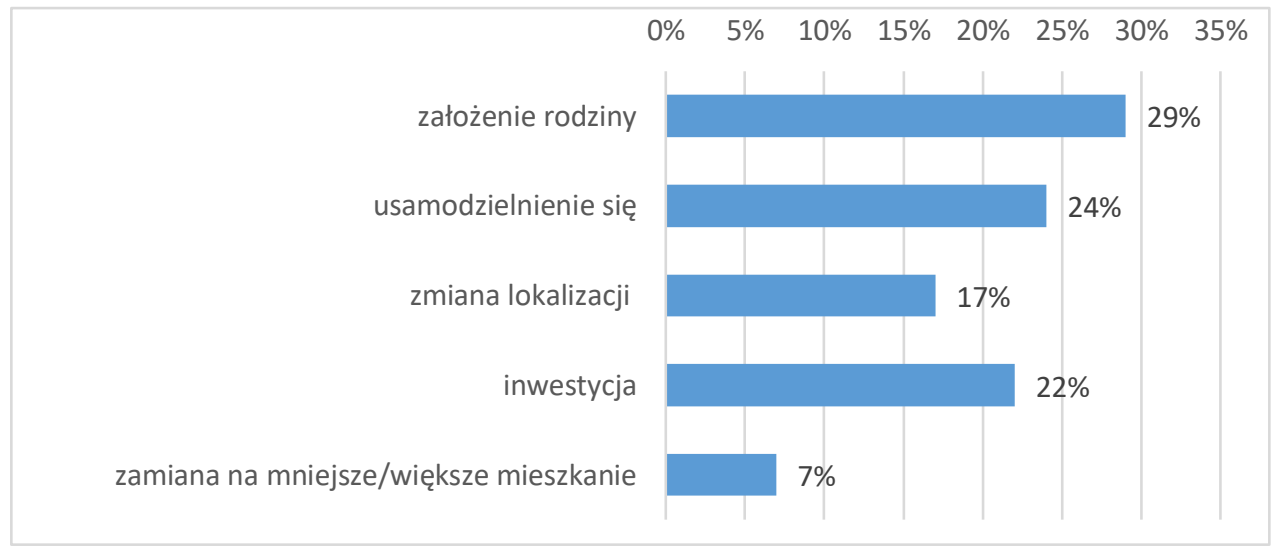

\section{Rysunek 3. Cel potencjalnego zakupu mieszkania}

Źródło: Opracowanie własne na podstawie badań ankietowych

Jak wynika z badań, najczęstszym powodem nabywania mieszkań jest chęć założenia rodziny - tej odpowiedzi udzieliło $29 \%$ ankietowanych. Drugie miejsce w tej klasyfikacji zajmuje chęć usamodzielnienia się - na ten powód wskazało $24 \%$ 
badanych. Obie odpowiedzi osiągnęły łącznie 53\%, co może świadczyć o przewyższającej ilości młodych respondentów. Spośród badanych 22\% rozważa zakup mieszkania w związku z inwestycją (Rysunek 3).

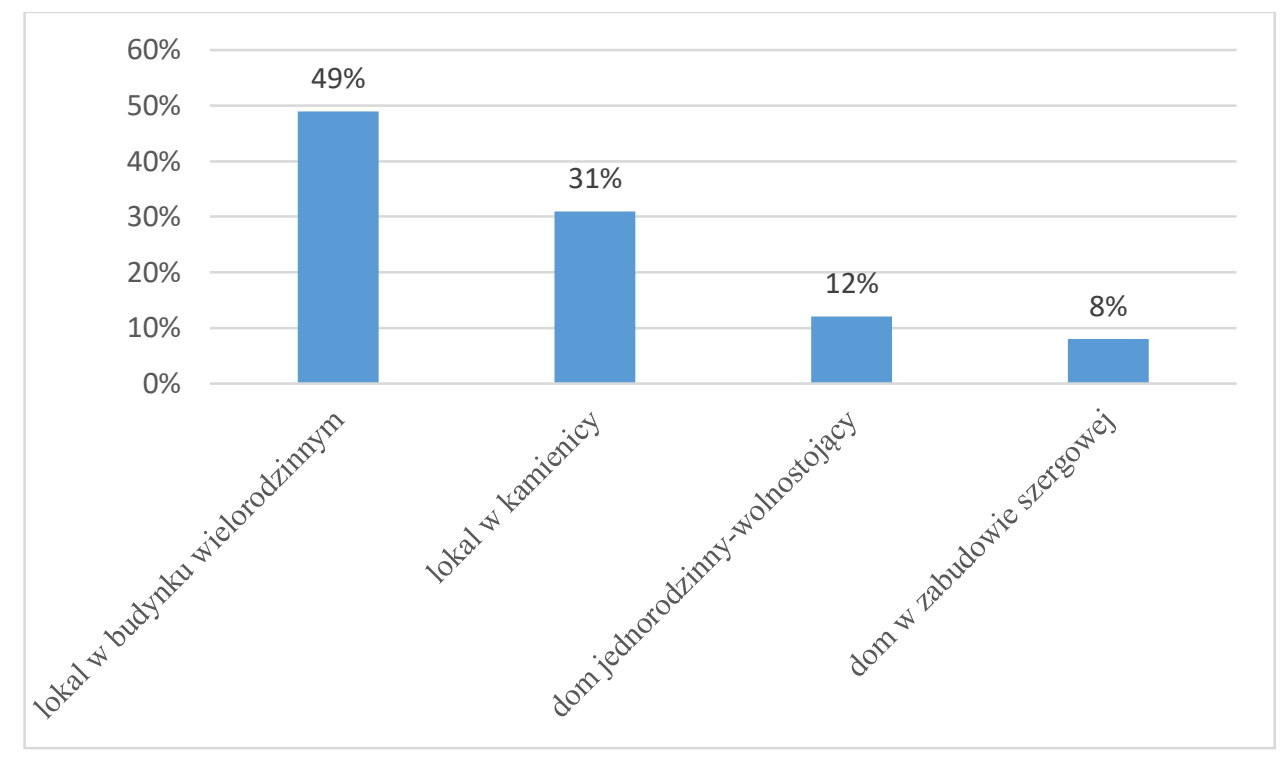

\section{Rysunek 4. Typ wybranego mieszkania}

Źródło: Opracowanie własne na podstawie badań ankietowych

Respondenci, najchętniej nabyliby lokal mieszkalny w budynku wielorodzinnym - takiej odpowiedzi udzieliło $49 \%$ badanych. Na drugim miejscu znalazł się dom wolnostojący - 31\% wskazań ankietowanych. Pozostała liczba ankietowanych wybrałaby dom jednorodzinny wolnostojący $-12 \%$ lub dom w zabudowie szeregowej-8\% (Rysunek 4).

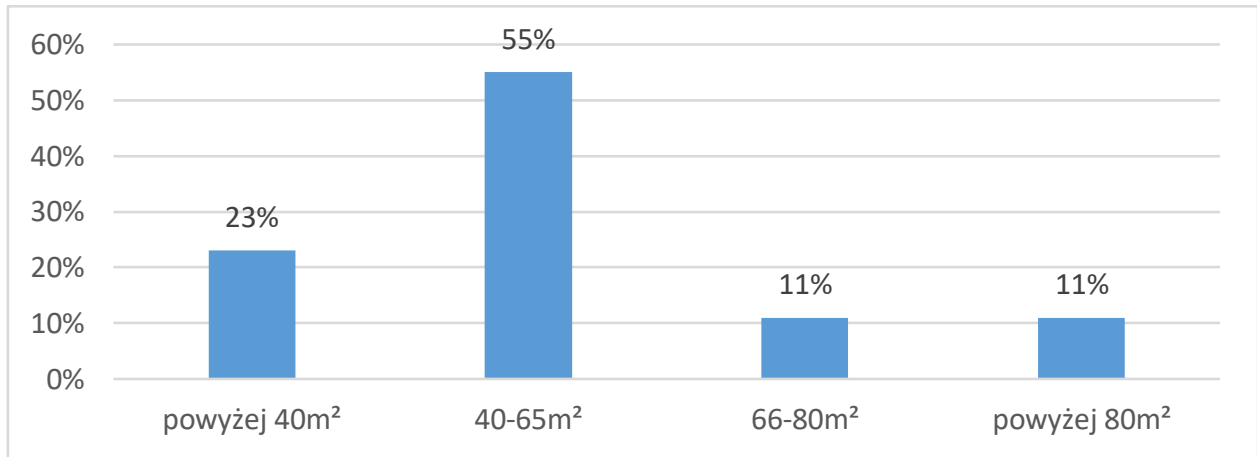

Rysunek 5. Preferowana powierzchnia mieszkaniowa

Źródło: Opracowanie własne na podstawie badań ankietowych 
Ankietowani wolą mniejsze mieszkania. Najmniejszą liczbę wskazań uzyskała powierzchnia poniżej $66-80 \mathrm{~m}^{2}$ oraz powyżej $80 \mathrm{~m}^{2}$. Powierzchnią tą zainteresowanych jest jedynie $22 \%$ ogółu odpowiadających. Najczęściej wybieraną powierzchnią mieszkalną wśród ankietowanych jest 40-65 $\mathrm{m}^{2}$ - tak odpowiedziało $55 \%$ respondentów. Drugą najpopularniejszą odpowiedzią w tej tematyce jest powierzchnia powyżej $40 \mathrm{~m}^{2}$ - taki metraż pragnie mieć $23 \%$ osób (Rysunek 5).

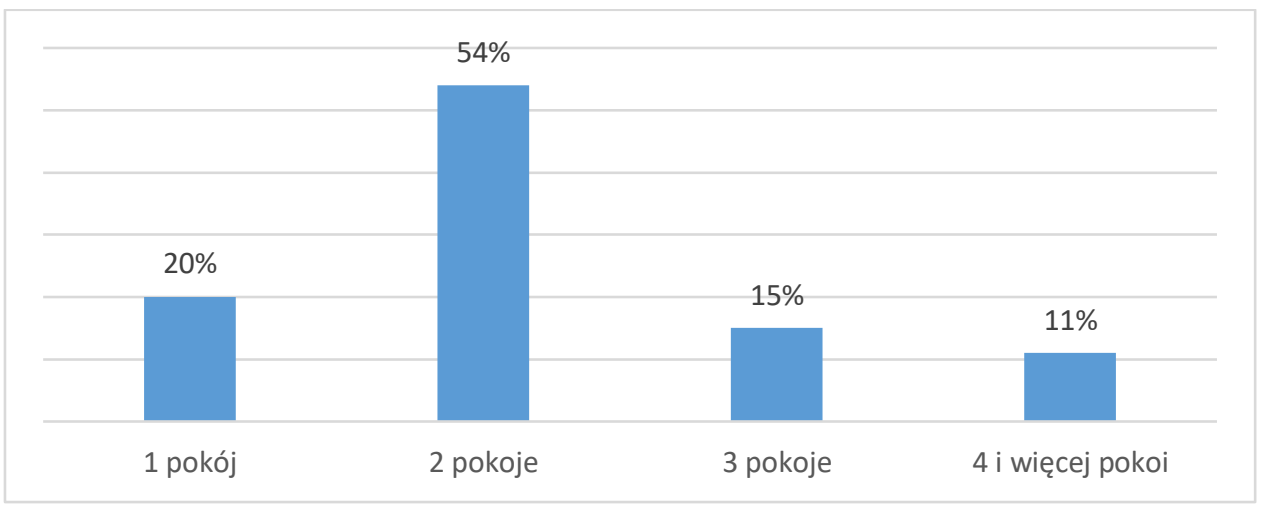

\section{Rysunek 6. Preferowana liczba pomieszczeń}

Źródło: Opracowanie własne na podstawie badań ankietowych

Rozpatrując liczbę pokoi, zauważyć można, iż ankietowani najchętniej nabyliby mieszkanie $\mathrm{z}$ dwoma pokojami. Tej odpowiedzi udzieliło 54\% badanych. Na drugim miejscu plasuje się mieszkanie z pojedynczym pokojem. Preferencję tę wskazało $20 \%$ osób. Najmniejszą popularnością wśród ankietowanych cieszy się mieszkanie posiadające co najmniej cztery pokoje (Rysunek 6 ).

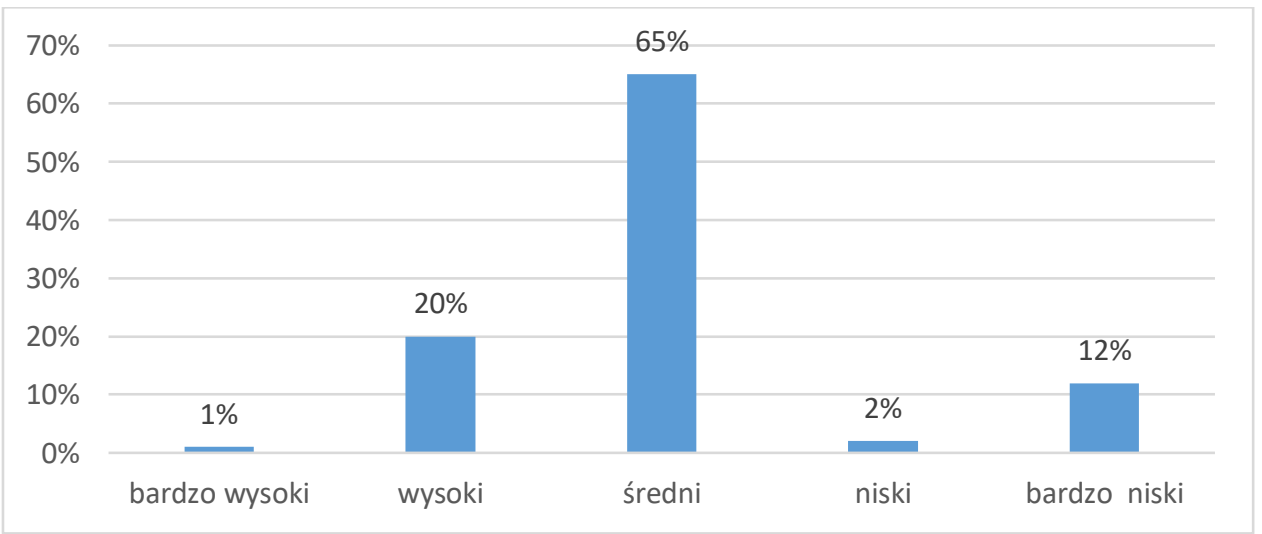

Rysunek 7. Poziom cen mieszkań w Częstochowie

Źródło: Opracowanie własne na podstawie badań ankietowych 
Ważnym elementem jest cena, dlatego również ankietowani mogli odnieść się do poziomu cen mieszkań na częstochowskim rynku nieruchomości. Według $65 \%$ badanych ceny mieszkań na terenie miasta osiągają średni poziom. Wśród badanych $20 \%$ ogółu stwierdza, że ceny nieruchomości mieszkaniowych są wysokie, natomiast tylko $12 \%$ ocenia poziom cen mieszkań jako bardzo wysoki. Warto nadmienić, że odpowiedź „bardzo wysoki poziom cen” osiągnęła 1\% głosów (Rysunek 7).

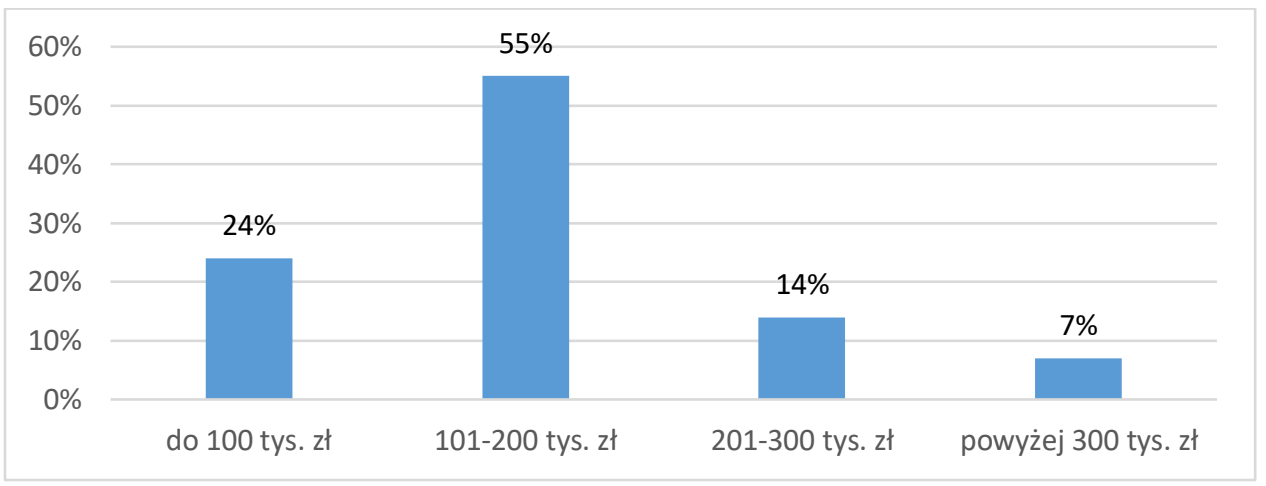

\section{Rysunek 8. Rozpatrywany przedzial cenowy mieszkań}

Źródło: Opracowanie własne na podstawie badań ankietowych

Najwięcej ankietowanych planuje zakup mieszkania za kwotę do 200 tys. zł, przy czym w grupie tej przeważają wskazania na przedział cenowy 101-200 tys. zł (55\% odpowiedzi). Niewiele osób rozważa zakup mieszkania kosztującego powyżej 200 tys. zł. Jedynie 14\% badanych bierze pod uwagę wydanie kwoty między 200 tys. zł a 300 tys. zł, natomiast $7 \%$ badanych rozważa zakup mieszkania kosztującego powyżej 300 tys. zł (Rysunek 8).

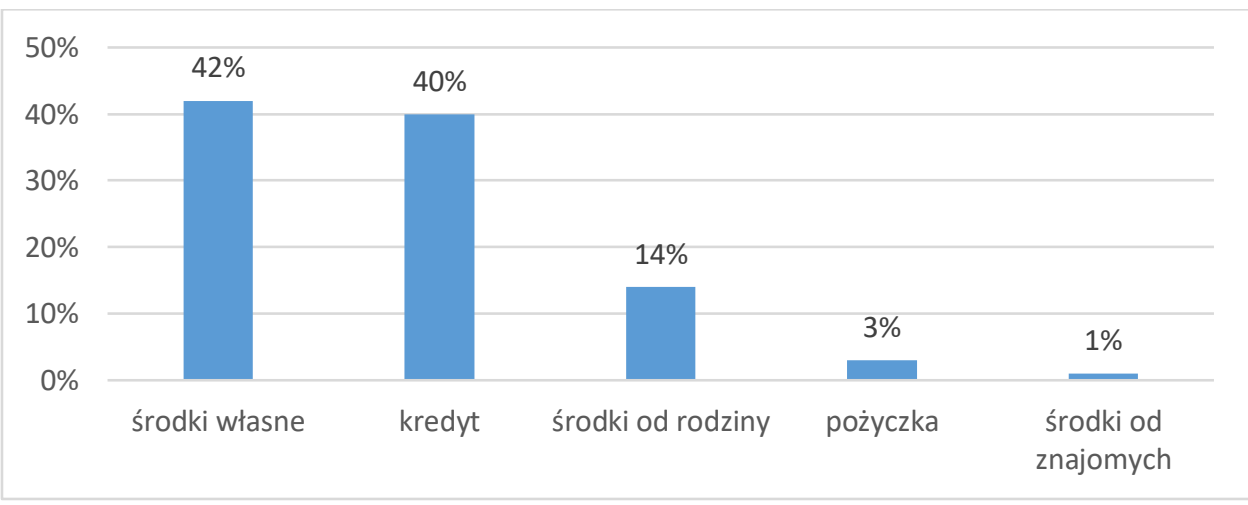

Rysunek 9. Wskazany sposób finansowania podczas zakupu mieszkania

Źródło: Opracowanie własne na podstawie badań ankietowych 
W kolejnym pytaniu ankietowani określili procentowo ewentualny sposób finansowania zakupu mieszkania. Najczęściej wybieraną opcją jest nabycie mieszkania przy wykorzystaniu środków własnych. Odpowiedź ta uzyskała 42\% poparcia respondentów. Wielu ankietowanych przyznaje wprost, że nie stać ich na nabycie mieszkania ze środków własnych. W tym celu dobrym rozwiązaniem jest kredyt, a odpowiedzi takiej udzieliło około $40 \%$ odpowiadających. Warto nadmienić, że 14 uczestników ankiety przyznało, że podczas zakupu mieszkania skorzysta z pomocy finansowej ze strony rodziny, natomiast tylko 1\% pozyska środki od znajomych (Rysunek 9).

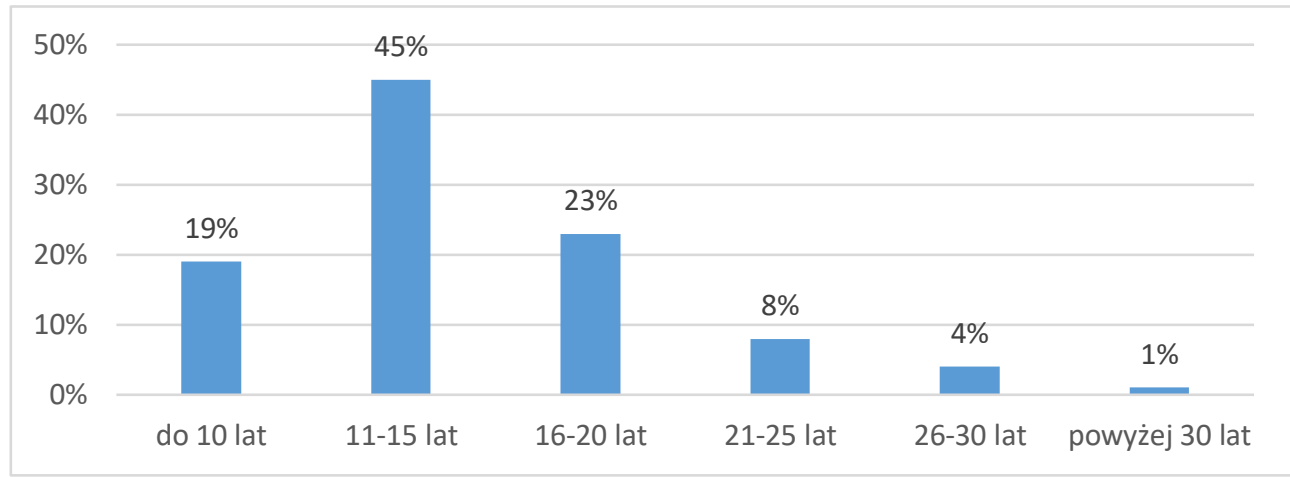

Rysunek 10. Wskazany okres kredytowania podczas zakupu mieszkania

Źródło: Opracowanie własne na podstawie badań ankietowych

Osoby, które wybrałyby kredyt jako źródło finansowania, wskazały również rozważany okres finansowania. Najczęściej wybieranym okresem kredytowania jest termin 11-15 lat. Odpowiedź ta uzyskała 45\% wskazań. Według 23\% ankietowanych godnym uwagi jest przedział 16-20 lat, natomiast 19\% ankietowanych uważa, że kredyt zaciągnięty na zakup mieszkania powinien zostać spłacony w terminie 10 lat (Rysunek 10).

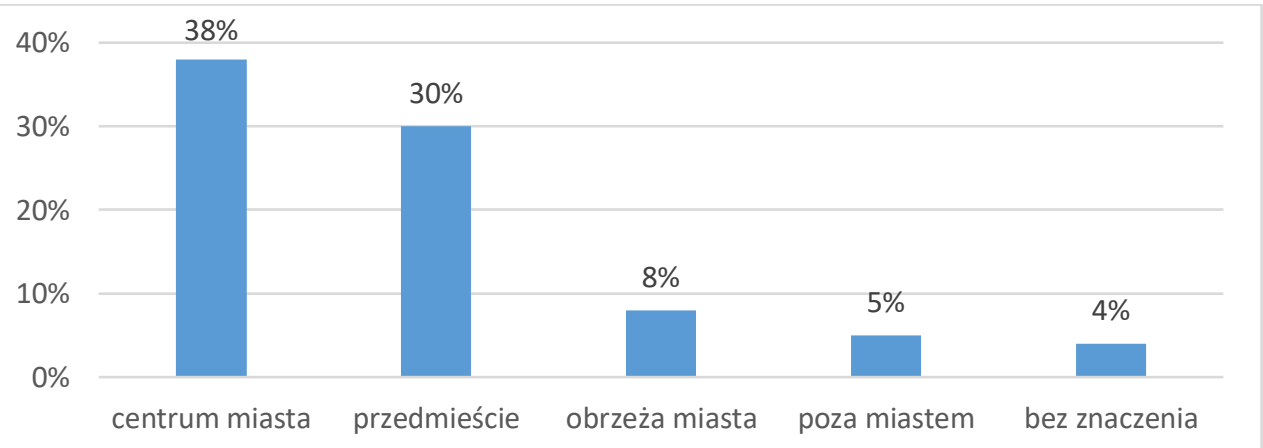

Rysunek 11. Najbardziej preferowana lokalizacja w mieście Częstochowie

Źródło: Opracowanie własne na podstawie badań ankietowych 
Dokonując wyboru lokalu mieszkalnego, klient kieruje się swoimi subiektywnymi odczuciami. Jednym z uwzględnianych elementów jest lokalizacja. Ankietowani najchętniej zakupiliby mieszkanie położone w centrum miasta $(38 \%)$ oraz na przedmieściach (30\%). Na trzecim miejscu znalazła się lokalizacja na obrzeżach miasta, właśnie w tym miejscu pragnie zamieszkać $8 \%$ ankietowanych. Co ciekawe, dla $4 \%$ badanych lokalizacja mieszkania nie ma znaczenia (Rysunek 11).

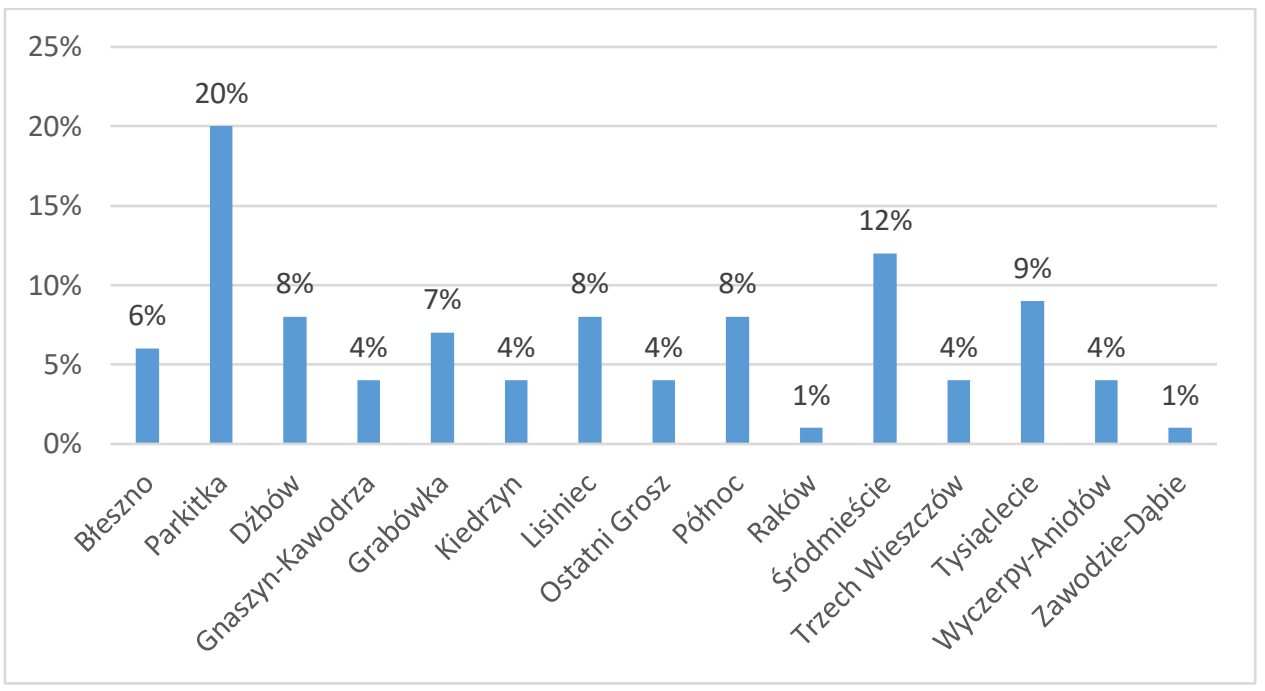

Rysunek 12. Dzielnice Częstochowy najczęściej wybierane podczas zakupu mieszkania

Źródło: Opracowanie własne na podstawie badań ankietowych

W drodze uszczegółowienia pytania dotyczącego lokalizacji okazało się, że wśród piętnastu dzielnic Częstochowy najbardziej preferowana według ankietowanych jest Parkitka - 20\% wskazań. Na drugim miejscu znajduje się Śródmieście $12 \%$ głosów. Natomiast ostatnie miejsce na podium zajmuje dzielnica Tysiąclecie, osiągająca przychylność 9\% respondentów. Dzielnice takie jak: Lisiniec, Dźbów, Północ są również popularne wśród respondentów, osiągnęły 8-procentowe poparcie. Reszta częstochowskich dzielnic osiągnęła poniżej 8\% głosów, między innymi: Grabówka - 7\%, Wyczerpy-Aniołów - 4\%, Kiedrzyn - 4\%, Trzech Wieszczów - 4\%. Dzielnicami, które uzyskały najmniejszą liczbę wskazań, są: Raków i Zawodzie, mające po $1 \%$ poparcia (Rysunek 12 ).

Uczestnicy badania zostali poproszeni o ocenę poszczególnych czynników ważnych podczas wyboru mieszkania. Według ankietowanych najistotniejszymi $\mathrm{z}$ nich są: cena, koszt utrzymania, poczucie bezpieczeństwa oraz liczba pokoi. Czynniki takie jak lokalizacja i sąsiedztwo cieszą się podobną popularnością. Elementy najmniej istotne dla badanych respondentów to tereny zielone. Czynniki te spośród elementów wymienionych poniżej osiągnęly najwięcej ocen o wartości 1 . Szczegółowy rozkład odpowiedzi prezentuje Tabela 1. 
Tabela 1. Znaczenie poszczególnych czynników podczas wyboru mieszkania

\begin{tabular}{|l|r|r|r|r|r|}
\hline \multirow{2}{*}{ Czynnik } & \multicolumn{6}{|c|}{ Waga * } \\
\cline { 2 - 6 } & $\mathbf{1}$ & $\mathbf{2}$ & $\mathbf{3}$ & $\mathbf{4}$ & \multicolumn{1}{c|}{$\mathbf{5}$} \\
\hline Cena & $2 \%$ & $7 \%$ & $5 \%$ & $29 \%$ & $57 \%$ \\
\hline Koszt utrzymania & $1 \%$ & $12 \%$ & $11 \%$ & $19 \%$ & $57 \%$ \\
\hline Poczucie bezpieczeństwa & - & $4 \%$ & $24 \%$ & $32 \%$ & $40 \%$ \\
\hline Lokalizacja & $8 \%$ & $13 \%$ & $25 \%$ & $25 \%$ & $29 \%$ \\
\hline Metraż & $11 \%$ & $7 \%$ & $11 \%$ & $39 \%$ & $32 \%$ \\
\hline Liczba pokoi & $9 \%$ & $5 \%$ & $26 \%$ & $26 \%$ & $34 \%$ \\
\hline Tereny zielone & $10 \%$ & $12 \%$ & $19 \%$ & $32 \%$ & $27 \%$ \\
\hline Sąsiedztwo & $1 \%$ & $19 \%$ & $24 \%$ & $27 \%$ & $29 \%$ \\
\hline
\end{tabular}

* (skala od 1 do 5, gdzie 1 - czynnik niemajacy wpływu, a 5 - czynnik majacy największy wptyw)

Źródło: Opracowanie własne na podstawie badań ankietowych

Korzystając z obliczeń średniej ważonej, łatwo jest stwierdzić, który z wymienionych czynników jest dla potencjalnych konsumentów nieruchomości mieszkaniowych najistotniejszy (Rysunek 13).

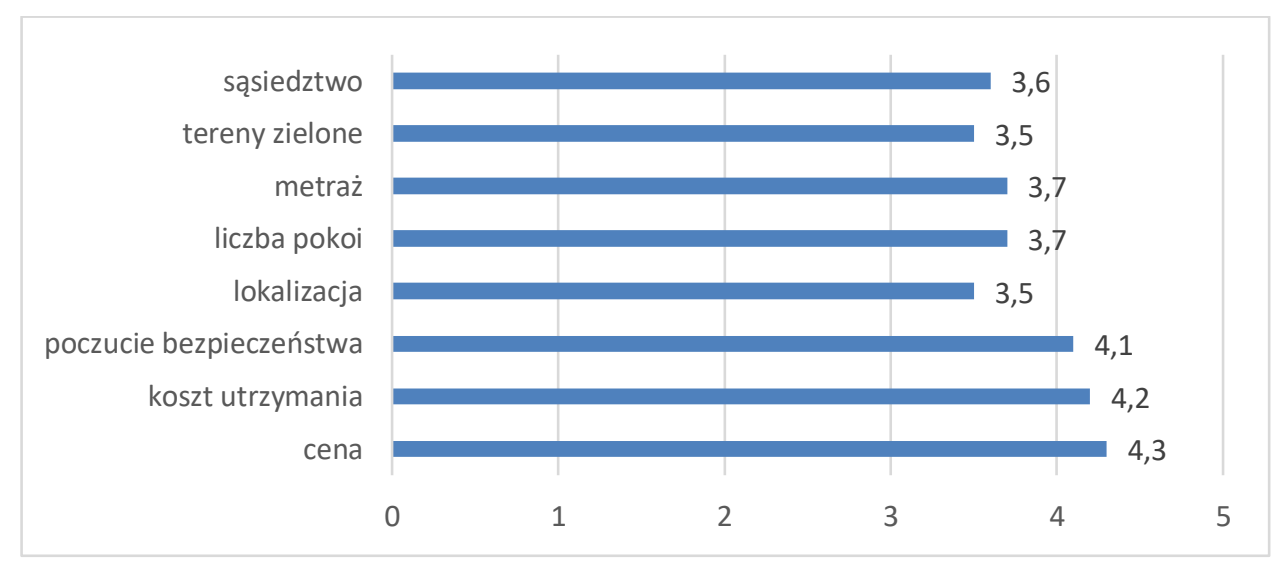

Rysunek 13. Średnia ważona czynników istotnych przy wyborze mieszkania

Źródło: Opracowanie własne na podstawie badań ankietowych

Pierwsze miejsce wśród elementów mających znaczenie podczas zakupu mieszkania jest jego cena, o średniej ważonej równej 4,3. Drugie miejsce w powyższej klasyfikacji zajmuje koszt utrzymania - o wartości 4,2. Jak zatem widać, elementy bezpośrednio związane $\mathrm{z}$ wydatkiem pieniężnym według ankietowanych są czynnikiem najczęściej branym pod uwagę. Warto wspomnieć, że wielu ankietowanych podczas wyboru mieszkania ceni sobie zarówno komfort psychiczny, jak i fizyczny, zatem poczucie bezpieczeństwa w oczach respondentów ma wartość 4,1. Rzecz jasna respondenci podczas zakupu mieszkania zwracają szczególną uwagę na elementy takie jak: liczba pokoi $(3,7)$ oraz metraż $(3,7)$. 
Tabela 2. Znaczenie poszczególnych czynników podczas wyboru mieszkania

\begin{tabular}{|l|c|c|c|c|c|}
\hline \multirow{2}{*}{\multicolumn{1}{c|}{ Czynnik }} & \multicolumn{5}{c|}{ Waga * } \\
\cline { 2 - 6 } & $\mathbf{1}$ & $\mathbf{2}$ & $\mathbf{3}$ & $\mathbf{4}$ & $\mathbf{5}$ \\
\hline Balkon & $5 \%$ & $15 \%$ & $27 \%$ & $37 \%$ & $16 \%$ \\
\hline Piwnica & $7 \%$ & $25 \%$ & $32 \%$ & $27 \%$ & $9 \%$ \\
\hline Strych/suszarnia & $11 \%$ & $17 \%$ & $22 \%$ & $33 \%$ & $17 \%$ \\
\hline Garaż & $4 \%$ & $13 \%$ & $19 \%$ & $37 \%$ & $27 \%$ \\
\hline Parking & $4 \%$ & $10 \%$ & $6 \%$ & $45 \%$ & $35 \%$ \\
\hline Winda & $7 \%$ & $16 \%$ & $24 \%$ & $15 \%$ & $38 \%$ \\
\hline Domofon & $6 \%$ & $16 \%$ & $13 \%$ & $13 \%$ & $52 \%$ \\
\hline Centralne ogrzewanie & $2 \%$ & $5 \%$ & $8 \%$ & $13 \%$ & $72 \%$ \\
\hline
\end{tabular}

* (skala od 1 do 5, gdzie 1 - czynnik niemający wplywu, a 5-czynnik mający największy wplyw)

Źródło: Opracowanie własne na podstawie badań ankietowych

Dla wielu osób elementami istotnymi przy podejmowaniu decyzji o zakupie mieszkania są np.: balkon, garaż czy też domofon. Ankietowani również dokonali oceny istotności tego typu elementów w procesie podejmowania decyzji o zakupie lokalu mieszkalnego. Ocenę najwyższą najczęściej przypisywano: centralnemu ogrzewaniu, domofonowi, windzie i parkingowi. Najwięcej wskazań o wadze 1 uzyskała suszarnia. Szczegółową strukturę wskazań przybliża Tabela 2.

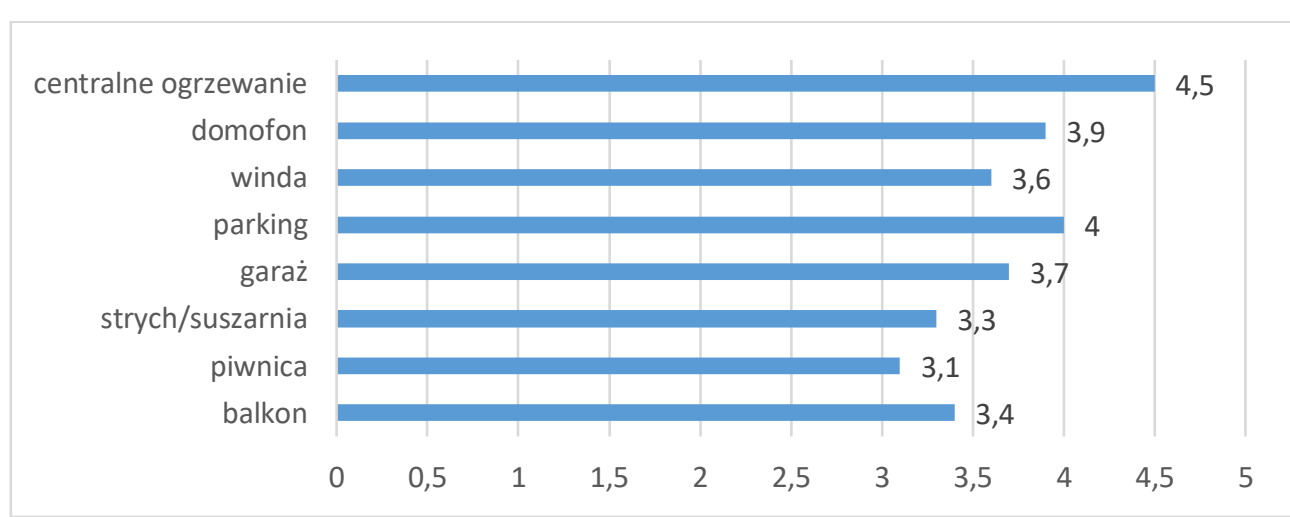

Rysunek 14. Średnia ważona czynników istotnych przy wyborze mieszkania

Źródło: Opracowanie własne na podstawie badań ankietowych

Podobnie jak przy poprzednich czynnikach, tutaj również została wyliczona średnia ważona dla każdego $\mathrm{z}$ elementów. Uwzględniając tę średnią, zauważyć można, że elementem najistotniejszym podczas dokonywania wyboru mieszkania jest centralne ogrzewanie, które uzyskało średnią ważoną równą 4,5. Elementem istotnym, zajmującym drugie miejsce, jest domofon - średnia ważona równa 3,9. 
Natomiast trzeci czynnik to garaż, który według ankietowanych przyjmuje wartość 3,7 . Według respondentów najmniej istotnym elementem mającym wpływ na zakup mieszkania jest piwnica - wartość 3,1 (Rysunek 14).

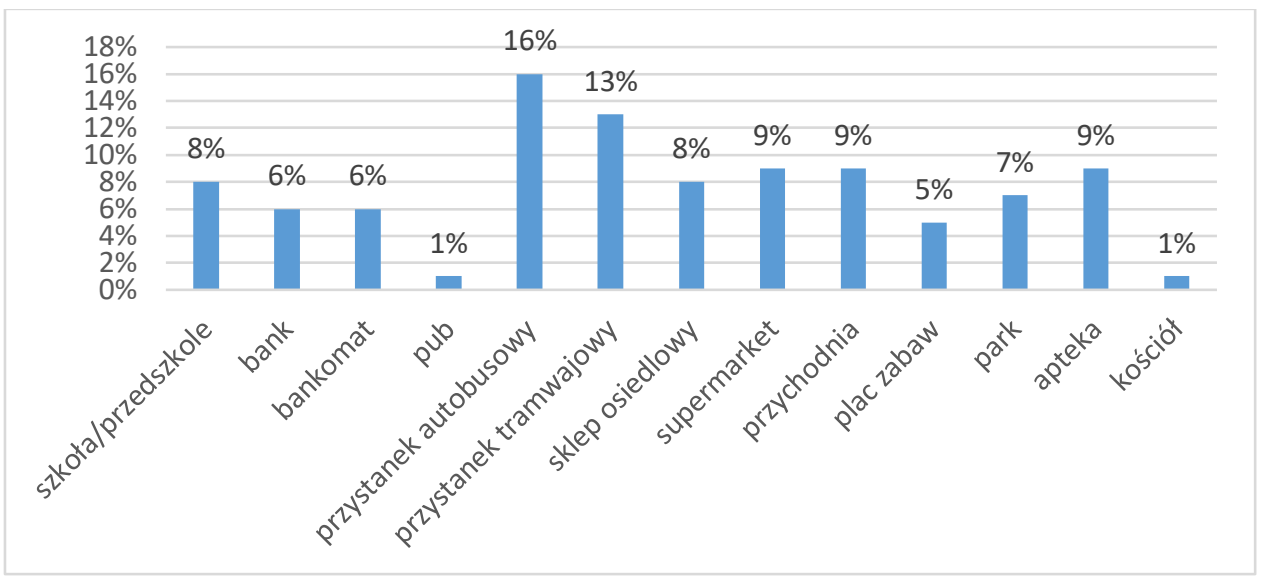

Rysunek 15. Obiekty preferowane w pobliżu zakupionego mieszkania

Źródło: Opracowanie własne na podstawie badań ankietowych

Według 16\% ankietowanych najchętniej widzianym obiektem znajdującym się w pobliżu wybranego mieszkania jest przystanek autobusowy. Na drugim miejscu znalazł się przystanek tramwajowy, tak zadecydowało 13\% respondentów. Poparcie 9\% osiągnęły: supermarket, apteka, przychodnia. Pozostałe obiekty osiągnęły noty poniżej tego poziomu, i tak sklep osiedlowy $-8 \%$, szkoła $-8 \%$, bank wraz z bankomatem po $6 \%$ wskazań. Najmniejszą liczbę wskazań uzyskał pub oraz kościół - osiągające po $1 \%$ głosów. Może to oznaczać, że są to najmniej pożądane obiekty przez potencjalnych klientów.

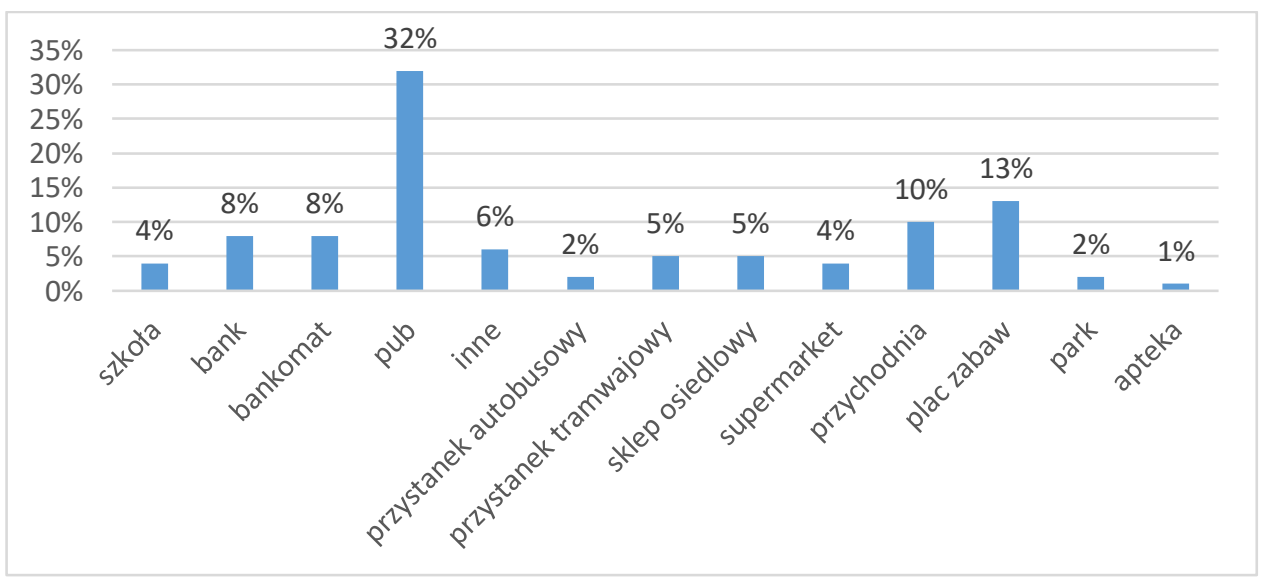

Rysunek 16. Obiekty najmniej preferowane w pobliżu zakupionego mieszkania

Źródło: Opracowanie własne na podstawie badań ankietowych 
Szczegółową strukturę wskazań obiektów najmniej preferowanych w pobliżu zakupionego mieszkania zaprezentowano na Rysunku 16. Wskazany wcześniej pub znalazł się na pierwszym miejscu wśród obiektów, które nie są do zaakceptowania w pobliżu zakupionego mieszkania. Ten obiekt uzyskał 32\% wszystkich wskazań. Kolejnym niechcianym obiektem jest plac zabaw - 13\% wskazań. Trzecią pozycję zajęła przychodnia - tego obiektu nie akceptuje 10\% respondentów. Pozostałe obiekty uzyskały poniżej $10 \%$ wszystkich odpowiedzi. Wśród nich znalazł się: bank, bankomat, przystanek tramwajowy.

Warto nadmienić, że w pytaniu tym można było liczyć również na propozycje stworzone przez respondentów w opcji „inne”. Ankietowani podali następujące propozycje: więzienie, śmieciowisko, dom publiczny, wysypisko śmieci czy kościół. Respondenci za obiekty najmniej uciążliwe uważają aptekę oraz park.

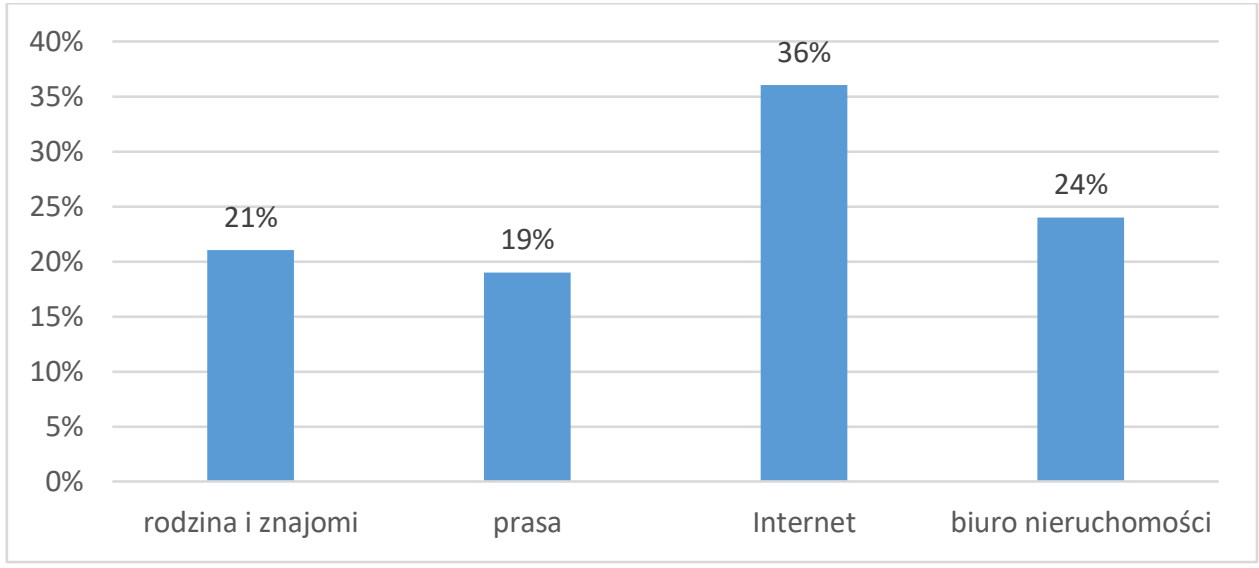

Rysunek 17. Najczęściej wybierane źródło informacji o rynku mieszkaniowym w Częstochowie

Źródło: Opracowanie własne na podstawie badań ankietowych

Źródła informacji o ofertach rynku nieruchomości są bardzo zróżnicowane, przy czym według ankietowanych najczęstszym źródłem informacji o rynku nieruchomości jest Internet. Ten rodzaj źródła wskazało 36\% ankietowanych. Według 21\% respondentów często wykorzystywane są informacje pochodzące od rodziny i znajomych. Podobny odsetek, 19\% ankietowanych, korzysta z ogłoszeń prasowych. Warto nadmienić, iż na popularności zyskują biura nieruchomości - ten sposób wybrało 24\% osób (Rysunek 17).

\section{Podsumowanie}

W badaniu ankietowym wzięło udział 100 mieszkańców miasta Częstochowy. Gromadzenie materiału badawczego odbyło się od października do grudnia 2017 roku. Respondenci zmagali się pytaniami zamkniętymi jedno- lub wielokrotnego wyboru. Kwestionariusz ankiety służył zbadaniu preferencji mieszkaniowych częstochowskiego społeczeństwa. 
Wraz ze zmianami otoczenia rynku nieruchomości zmianie ulegają również oczekiwania potencjalnych nabywców. Jak wynika $\mathrm{z}$ badań ankietowych, nabycie mieszkania to poważna decyzja, a jej podjęcia dokonuje się pod wpływem rozmaitych czynników. Większa ilość respondentów przyznała, że na dzień dzisiejszy nie posiada własnego mieszkania, ponadto nie planuje również jego nabycia w najbliższym czasie. Ponad połowa ankietowanych przyznaje również, że transakcji tej dokona nie wcześniej niż za 5 lat lub jeszcze później. Zakup mieszkania wiąże się z konkretnymi planami. Wśród ankietowanych najczęściej wymienianym powodem zakupu mieszkania jest chęć stworzenia rodziny. Natomiast $24 \%$ odpowiadających wiąże tę decyzję z możliwością usamodzielnienia się.

Jak wiadomo, od naszych preferencji zależy, jaką powierzchnię czy też liczbę pomieszczeń będzie posiadać wymarzone mieszkanie. Według ponad 50\% ankietowanych nabyte mieszkanie powinno mieć powierzchnię $40-65 \mathrm{~m}^{2}$, i posiadać 2 pokoje.

Zakup lokalu mieszkalnego wiąże się $\mathrm{z}$ ogromnymi kosztami, dlatego wiele osób korzysta $z$ różnych sposobów finansowania. Rozwiązaniem najpopularniejszym wśród ankietowanych jest wykorzystanie środków własnych - tej odpowiedzi udzieliło $42 \%$ osób. Nie każdy jednak posiada dostateczny zasób kapitału własnego, $40 \%$ ankietowanych skorzystałoby z finansowania zewnętrznego - kredytu.

Respondenci mogli wypowiedzieć się również na temat upodobań w sprawie dzielnic miasta. Największą przychylność mieszkańców miasta uzyskała Parkitka oraz Śródmieście. Natomiast najmniejszą popularnością cieszy się Zawodzie i Raków. Ankieta wykazała, że preferencje mieszkaniowe częstochowian są bardzo rozmaite, identycznie jak rynek nieruchomości mieszkaniowych.

\section{Literatura}

Baranowski W., Buczek G. (2008), Encyklopedia wiedzy o nieruchomościach, Europejski Instytut Nieruchomości, Kraków.

Bończak-Kucharczyk E. (2014), Zarzadzanie nieruchomościami mieszkalnymi. Aspekty prawne i organizacyjne, Wolters Kluwer, Warszawa.

Bryx M. (2006), Rynek nieruchomości. System i funkcjonowanie, Poltex, Warszawa.

Gawron H. (2010), Podstawy zarzadzania nieruchomościami, Wydawnictwo Uniwersytetu Ekonomicznego w Poznaniu, Poznań.

Gorzeń-Mitka I., Grabiec O. (2015), Motywy zakupu mieszkań w świetle badań nabywców na lokalnym rynku nieruchomości mieszkaniowych, „Zeszyty Naukowe Wyżzzej Szkoły Humanitas. Zarządzanie", nr 4, s. 291-299. DOI: 10.5604/18998658.1186444

Lemańska-Majdzik A., Tomski P. (2014), Identyfikacja czynników sukcesu przedsiębiorstwa na rynku nieruchomości. Przypadek ushug pośrednictwa w obrocie nieruchomościami, „Świat Nieruchomości”, nr 1, s. 5-9. DOI: 10.14659/worej.2014.87.01

Lis P. (2008), Polityka państwa w zakresie finansowania inwestycji mieszkaniowych, C.H. Beck, Warszawa.

Łaszek J. (2006), Rynek nieruchomości mieszkaniowych i jego specyfika, [w:] Kucharska-Stasiak E. (red.), Ryzyka banku w zakresie określania wartości nieruchomości dla celów kredytowych $w$ Polsce na tle trendów w Unii Europejskiej, Zeszyt Hipoteczny nr 23, Fundacja na rzecz Kredytu Hipotecznego, Warszawa, s. 155-160. 
Najbar K., Uhruska M. (2006), Strategie zarządzania nieruchomościami, Wydawnictwo Akademii Ekonomicznej w Krakowie, Kraków.

Nalepka A. (2006), Zarządzanie nieruchomościami. Wybrane zagadnienia, Wydawnictwo Akademii Ekonomicznej w Krakowie, Kraków.

Nowak M., Skotarczak T. (2013), Podstawy gospodarowania nieruchomościami, CeDeWu, Warszawa.

9. Rozporządzenie Ministra Infrastruktury z dnia 12 kwietnia 2002 r. w sprawie warunków technicznych, jakim powinny odpowiadać budynki i ich usytuowanie (Dz.U. $2002 \mathrm{nr} 75$ 10. poz. 690 , z. późn. zm.).

11. Sitek M. (2010), Bankowość hipoteczna i rynek nieruchomości, Key Text. Warszawa. Sobczak A. (2010), Plany zarządzania nieruchomościami, Poltext, Warszawa.

12. Ustawa z dnia 14 czerwca1994 r. o własności lokali (Dz.U. 1994 nr 85 poz. 388, z. późn. zm.).

13. Ustawa $\mathrm{z}$ dnia 2 lipca 1994 r. o najmie lokali mieszkalnych i dodatkach mieszkaniowych 14. (Dz.U. 1994 nr 105 poz. 509, z. późn. zm.).

15. Ustawa z dnia 21 sierpnia 1997 r. o gospodarce nieruchomościami (Dz.U. 1997 nr 115 poz. 16. 741, z późn. zm.)

\title{
RESIDENTIAL PROPERTY MANAGEMENT FROM THE PERSPECTIVE OF BUYERS' EXPECTATIONS
}

\begin{abstract}
The aim of the study is to show, evaluate and analyze the expectations of residential real estate buyers. The empirical part of the article presents the characteristics of residential real estate and the specificity of managing housing premises. In the empirical part, a questionnaire was used while the research method was a survey. The study was conducted among the residents of Częstochowa. The research results provide information about purchasing preferences of residential real estate buyers in the city. The information obtained in this study, on the one hand, shed some light on the buyers' needs, and on the other, it can be a suggestion for entities creating the supply on the real estate market.
\end{abstract}

Keywords: flat, real estate market, residential real estate, management of residential real estate 